$\xi=-1$

\title{
Developing Educational Statistics Module by Using Problem-Based Learning (PBL) for the Students of the Faculty of Teacher Training and Education of Bung Hatta University, Padang, Indonesia
}

\author{
Khairudin $^{1 *}$, Karmila Suryani ${ }^{2}$, A.D. Trisno George Selvi ${ }^{3}$, Uswatun Hasanah ${ }^{4}$ \\ ${ }^{I}$ Faculty of Teacher Training and Education, BungHatta University \\ ${ }^{2}$ Faculty of Teacher Training and Education, BungHatta University \\ ${ }^{3}$ Faculty of Teacher Training and Education, Bung Hatta University \\ ${ }^{4}$ Padang State University \\ *Corresponding author E-mail:khairuddin@bunghatta.ac.id
}

\begin{abstract}
This study aims to develop a Problem-Based Learning (PBL)-oriented module for Educational Statistics course, and to test whether or not such such module is feasible to be used as learning material for the students. The module was developed by applying ADDIE research and development model which includes the following stages: (1) Analysis, (2) Design, (3) Development, (4) Implementation, and (5) Evaluation. The module eligibility was tested by media experts, materials experts, and students. The results of testing showed that the feasibility of the module according to the media and material experts are $82.6 \%$ and $87.9 \%$ respectively. In addition, the practicality tests in a small scale resulted in an average percentage of $85.03 \%$, and the module effectiveness test obtained a percentage of $65 \%$. Therefore, it can be concluded that the Educational Statistics module for the students is worth developing and feasible to be used as a guide in the learning process at the Faculty of Teacher Training and Education.
\end{abstract}

Keywords: Statistics Module, Problem Based Learning, Model ADDIE.

\section{Introduction}

Quality of learning process and outcomes in college can be achieved by applying various learning strategies and developing variety of teaching materials. It is prescribed in the Decree of the Minister of Higher Education No. 44 of 2015 on National Higher Education Standard (SNPT) which states that National Education Standard serves as the minimum criteria for learning at higher education level in all colleges or universities throughout the jurisdiction of the Unitary State of the Republic of Indonesia. Article 32 of the Ministerial Decree stipulates that the facilities for the education standard as meant in the abovemention Decree should at least consist of educational media, books, electronic books and repositories. But, as a matter of fact, the media and the books being used as teaching materials for the students are still limited in number and variety, most of them still in the form supporting books and materials presented by lecturers only. The existing source books, especially those for Educational Statistics course have not yet able to accommodate the students with sufficient knowledge to understand the material well. Meanwhile, the Statistical Education course which contains plenty of learning material should be presented in a very limited time. This makes it difficult for students to apply the concept of Statistics in solving their research problems. A module as the learning material that serves as the open-source information can be used by teachers and students in learning process. According to Daryanto (2013), module is a complete and systematic teaching material that contains a set of planned learning experience and is designed to help students achieve learning objectives. The modules can be self-studied by the students (self-instructional) and are written for one set of competencies or a package of instructional materials. Furthermore, Wena (2010) states that module as a teaching material must contain certain characteristics that distinguish it from other teaching materials. A typical characteristics of module among others: 1) self contained, 2) reliance on individual differences, 3) association, 4) use of various media, 5) active student participation, 6) direct reinforcement, and 7) monitoring evaluation strategy. Modules are presented using good instructional language equipped with interesting and meaningful illustrations for students to easily use them.

\section{Literature Review}

The use of modules for improving learning outcomes has been widely studied. Aisyah and Purwoko (2011) used modules to improve learning outcomes in the course: Curriculum Studies. Sengupta et al.(2017) focused on developing education modules for various aspects of sustainable manufacturing, but the modules has not yet been tested for eligibility. Wijana and Suardani (2016) have used the spreedsheet in the statistics module for Accounting Department but only applied descriptive statistics, regression, index numbers and time series. Meanwhile, Surindra et.al (2017) developed PBL-Based Economic Statistics II module in Economics Education Study Program of Nusantara PGRI University, Ke- 
diri. Furthermore, Tarmizi and Bayat (2010) evaluated the possible outcomes of PBL application among postgraduate students who took Educational Statistic course. However, so far no researcher has designed the PBL-based educational statistics module yet.

\section{Methods}

This paper uses ADDIE model which has been developed by Culatta (2018) as shown in figure 1.

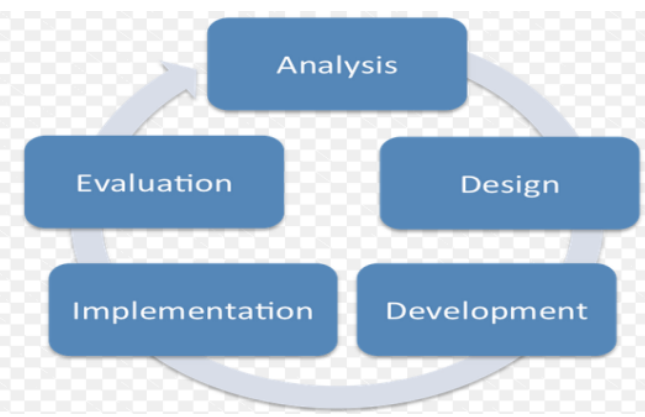

Fig 1. ADDIE Development Model by Culatta

ADDIE model as used in this study stands for Analysis, Design, Development, Implementation, and Evaluations. By applying the steps at ADDIE development model, the process of developing the Statistics module can be seen in Figure 2. Preliminary observation was conducted on 30 students of study program of Informatics and Computer Engineering Education (PTIK) of Bung Hatta University who took educational statistics class. Since the students only used conventional dictates on educational statistics, 10 of whom said in an interview that they faced difficulties in understanding the learning materials.

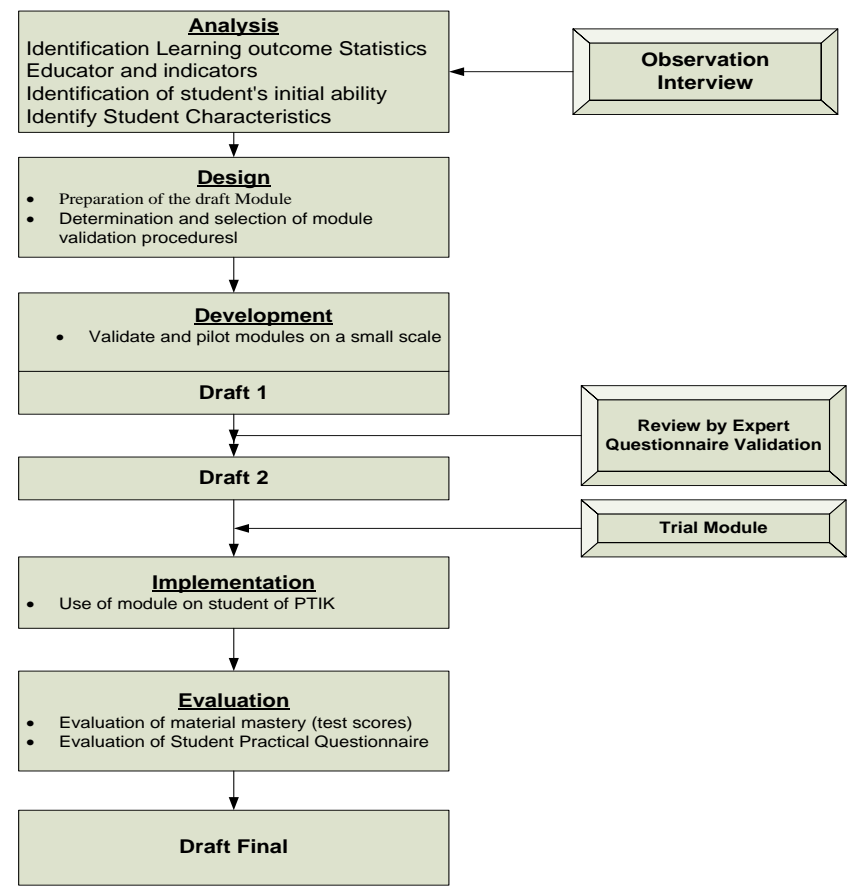

Fig 2. Module Creation Process

\section{Research Instrument}

In this research, the instrument being used is divided into 3 instruments, namely:

\subsection{Validation Questionnaire for the Experts}

The validity sheet is distributed to material expert (content) and media expert (module). 3 lecturers of the mathematics education program of Bung Hatta University shall act as expert validators, and 2 lecturers of informatics and computer engineering education of Bung Hatta University shall provide their expertise as media validators. Grid of content and media validation sheet are shown in Tables 1 and 2.

Table 1. Material Validation Sheet Grid (Material Expert)

\begin{tabular}{|c|c|c|c|}
\hline Criteria & & Indicator & Assessment Item \\
\hline \multirow[t]{4}{*}{$\begin{array}{l}\text { Aspect of } \\
\text { Eligibility of } \\
\text { content }\end{array}$} & A. & $\begin{array}{l}\text { Material Com- } \\
\text { pliance with LO }\end{array}$ & 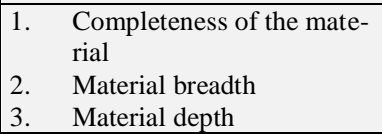 \\
\hline & B. & $\begin{array}{l}\text { Material Accu- } \\
\text { racy }\end{array}$ & 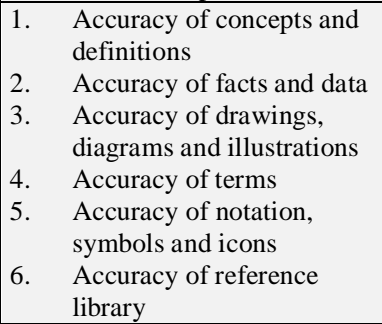 \\
\hline & $\mathrm{C}$. & $\begin{array}{l}\text { Material Up- } \\
\text { dates }\end{array}$ & \begin{tabular}{|l} 
1. \\
Material compatibility with \\
the development of statis- \\
tics \\
2. $\begin{array}{l}\text { Examples and cases in } \\
\text { everyday life }\end{array}$ \\
3. $\begin{array}{l}\text { Pictures, diagrams and } \\
\text { illustrations in everyday } \\
\text { life }\end{array}$ \\
4. Library updates
\end{tabular} \\
\hline & D. & $\begin{array}{l}\text { Pushing Curi- } \\
\text { osity }\end{array}$ & \begin{tabular}{|ll}
$\begin{array}{l}\text { 1. } \\
\text { 2. }\end{array}$ & $\begin{array}{l}\text { Cncourage curiosity } \\
\text { questions }\end{array}$ \\
\end{tabular} \\
\hline \multirow[t]{4}{*}{$\begin{array}{l}\text { Aspect of } \\
\text { feasibility of } \\
\text { presentation }\end{array}$} & A. & $\begin{array}{l}\text { Presentation } \\
\text { Technique }\end{array}$ & 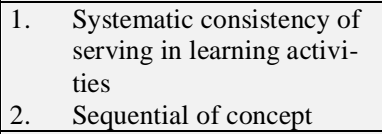 \\
\hline & & $\begin{array}{l}\text { Presentation } \\
\text { Support }\end{array}$ & 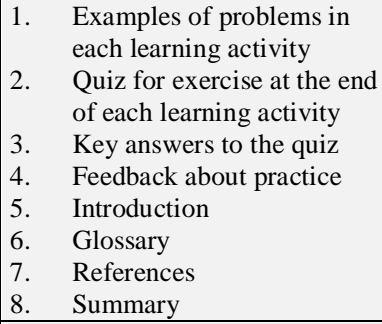 \\
\hline & C. & $\begin{array}{l}\text { Presentation of } \\
\text { learning }\end{array}$ & $\begin{array}{ll}\text { 1. Performance of learning } \\
\text { participants }\end{array}$ \\
\hline & D. & $\begin{array}{l}\text { Coherence and } \\
\text { sequence of } \\
\text { thought flow }\end{array}$ & $\begin{array}{l}\text { 1. The linkage between learn- } \\
\text { ing activities / sub learning } \\
\text { activities / paragraph } \\
\text { Wholeness of meaning in } \\
\text { learning activities / sub- } \\
\text { activity learning / para- } \\
\text { graph }\end{array}$ \\
\hline $\begin{array}{l}\text { Aspects of } \\
\text { Problem- } \\
\text { Based Learn- } \\
\text { ing (PBL) } \\
\text { Orientation }\end{array}$ & A. & $\begin{array}{l}\text { PBL compo- } \\
\text { nents }\end{array}$ & $\begin{array}{l}\text { 1. Student orientation on the } \\
\text { problem } \\
\text { 2. Organizing the students to } \\
\text { learn } \\
\text { 3. Guiding group learning } \\
\text { experience } \\
\text { 4. Preparing and presenting } \\
\text { the work } \\
\text { 5. Analyzing and evaluating } \\
\text { the problem-solving pro- } \\
\text { cess }\end{array}$ \\
\hline
\end{tabular}

Source: Dikti (2017), Muljono ( 2007)

Table 2. Media Expert Questionnaire Grid

\begin{tabular}{|c|c|c|}
\hline Criteria & Indicator & Assessment Item \\
\hline \multirow[t]{2}{*}{$\begin{array}{l}\text { 1. Aspect of } \\
\text { feasibil- } \\
\text { ity of } \\
\text { graphic }\end{array}$} & $\begin{array}{l}\text { A. Module } \\
\text { Size }\end{array}$ & $\begin{array}{l}\text { 1. Conformity of module size } \\
\text { with iso standard } \\
\text { 2. Suitability of the size with the } \\
\text { material / content of the mod- } \\
\text { ule }\end{array}$ \\
\hline & $\begin{array}{l}\text { B. Cover } \\
\text { Design }\end{array}$ & $\begin{array}{l}\text { 1. The appearance of the layout } \\
\text { elements on the front, rear and }\end{array}$ \\
\hline
\end{tabular}




\begin{tabular}{|c|c|c|c|}
\hline & & $\begin{array}{l}2 . \\
3 .\end{array}$ & $\begin{array}{l}\text { back cover in harmony has a } \\
\text { rhythm and unity and con- } \\
\text { sistent } \\
\text { The color of the elements of } \\
\text { the layout of the harmonic and } \\
\text { clarify the function } \\
\text { The letters used are interesting } \\
\text { and easy to read } \\
\text { a. The title of the letters is } \\
\text { more dominant and propor- } \\
\text { tional than the module size, } \\
\text { author name } \\
\text { b. The title color of the mod- } \\
\text { ule contrasts with the back- } \\
\text { ground color } \\
\text { Do not use too many combina- } \\
\text { tions of letters } \\
\text { Illustration of module cover } \\
\text { a. Describe the content / } \\
\text { teaching material and re- } \\
\text { veal the object's charac- } \\
\text { ter } \\
\text { Shape, color, size, pro- } \\
\text { portion of objects ac- } \\
\text { cording to reality. }\end{array}$ \\
\hline & $\begin{array}{l}\text { C. Design } \\
\text { of mod- } \\
\text { ule con- } \\
\text { tents }\end{array}$ & 4. & $\begin{array}{l}\text { Consistency of layout } \\
\text { a. Placement of layout ele- } \\
\text { ments is consistent withthe } \\
\text { pattern } \\
\text { b. The separation between } \\
\text { paragraphs is clear } \\
\text { The element of harmonic } \\
\text { layout } \\
\text { a. Print field and proportional } \\
\text { margin } \\
\text { b. Spacing between texts and } \\
\text { illustrations accordingly } \\
\text { Complete layout elements } \\
\text { a. Title of learning activity, } \\
\text { learning activity subtitle, and } \\
\text { folio page numbers } \\
\text { b. Illustration and caption } \\
\text { The layout speeds up the page } \\
\text { a. Placement of decoration / il- } \\
\text { lustration as the background } \\
\text { does not interfere with title, } \\
\text { text, page numbers } \\
\text { b. Placement of titles, sub- } \\
\text { heads, illustrations, and cap- } \\
\text { tions does not interfere with } \\
\text { understanding } \\
\text { The typography of module } \\
\text { contents simple } \\
\text { a. Not using too many fonts } \\
\text { b. The use of letter variance } \\
\text { (bold, italic, all capitals, small } \\
\text { capital) is not excessive } \\
\text { c. The width of the normal } \\
\text { text arrangement } \\
\text { a. Spacing between lines of } \\
\text { normal text arrangement } \\
\text { c. Creative and dynamic } \\
\text { Topography of module con- } \\
\text { tents facilitate understanding } \\
\text { a. The tiers of the titles are } \\
\text { clear, consistent and propor- } \\
\text { tional } \\
\text { b. Cut marks } \\
\text { Illustration of content } \\
\text { m. Able to reveal the meaning / } \\
\text { b. The the object } \\
\text { accurate and } \\
\text { ange is }\end{array}$ \\
\hline \multirow[t]{3}{*}{$\begin{array}{l}\text { 2. Language } \\
\text { Feasibility } \\
\text { Aspect }\end{array}$} & $\begin{array}{l}\text { A. Straight- } \\
\text { forward }\end{array}$ & $\begin{array}{l}1 . \\
2 . \\
3 .\end{array}$ & $\begin{array}{l}\text { Accuracy of sentence structure } \\
\text { Effectiveness of sentences } \\
\text { Kindness of the term }\end{array}$ \\
\hline & \begin{tabular}{|l|} 
B. Comuni- \\
cative
\end{tabular} & 1. & $\begin{array}{l}\text { Understanding of messages or } \\
\text { information }\end{array}$ \\
\hline & C. Dialogic & 1. & Ability to motivate students \\
\hline
\end{tabular}

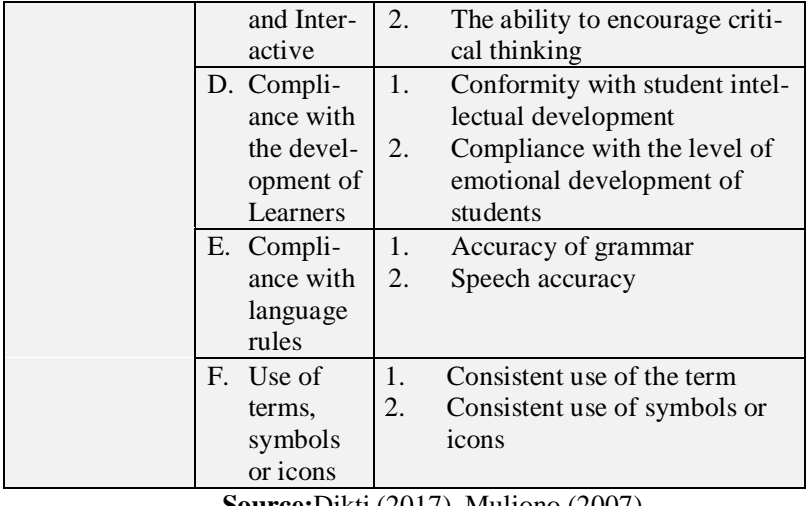

Source:Dikti (2017), Muljono (2007)

The grid generates a questionnaire by taking a Likert scale from 1 to 4 with criteria as follows: $1=$ Poor, $2=$ Weak, $3=$ Good and 4 = Very good.

\subsection{Student Practicality Questionnaire}

Data collection with a sheet of practicality or questionnaire is useful for obtaining information about the student's response to the Education Statistics module by checking the list $(\sqrt{ })$ in the available column for each of the proposed statements with the questionnaire in Table 3.

Tabel 3. Practicality Grid Sheet of Learning Media

\begin{tabular}{|c|c|c|}
\hline No. & $\begin{array}{l}\text { Practicality } \\
\text { Variable }\end{array}$ & Indicators \\
\hline 1. & $\begin{array}{l}\text { Student In- } \\
\text { terest }\end{array}$ & $\begin{array}{l}\text { 1) The desire of students to follow the } \\
\text { learning. } \\
\text { 2) Students keeness of using the module. } \\
\text { 3) Student interest in learning with a } \\
\text { module designed. } \\
\text { 4) Student interest in the image on the } \\
\text { module. } \\
\text { 5) Boredom in learning using learning } \\
\text { module }\end{array}$ \\
\hline 2. & $\begin{array}{l}\text { Process Us- } \\
\text { age }\end{array}$ & $\begin{array}{l}\text { 1) Students are easy to accept and under- } \\
\text { stand the concept of subject matter } \\
\text { 2) Students are easy to use design mod- } \\
\text { ule. } \\
\text { 3) Through the module, students more } \\
\text { easily find the concept of learning. } \\
\text { 4) Students easily find concepts learned } \\
\text { with real contexts in everyday life. }\end{array}$ \\
\hline 3. & $\begin{array}{l}\text { Increased } \\
\text { Student Activi- } \\
\text { ty }\end{array}$ & $\begin{array}{l}\text { 1) Increased student learning activities. } \\
\text { 2) Train students to think critically. } \\
\text { 3) Train students' self-study. } \\
\text { 4) Make students better understand the } \\
\text { material. }\end{array}$ \\
\hline 4. & $\begin{array}{l}\text { Sufficiency } \\
\text { of Time }\end{array}$ & $\begin{array}{l}\text { 1) The time provided to use media is } \\
\text { enough. } \\
\text { 2) The learning process is more effective } \\
\text { and interactive. }\end{array}$ \\
\hline 5. & Evaluation & $\begin{array}{l}\text { 1) Exercise can help students to better } \\
\text { understand the material. } \\
\text { 2) Exercise can be a benchmark of stu- } \\
\text { dents in understanding the materials of Ed- } \\
\text { ucation statistics }\end{array}$ \\
\hline
\end{tabular}

\subsection{Effectiveness Test of the Module}

Aspects of the effectiveness of the modules observed in the learning process using this medium is to test the statistical material 


\section{Data analysis technique}

Test module validation using Daryanto (2013) feasibility test by calculating the score and maximum score with scale $1-4$, and using equation (1)

$$
\text { Validity Expert }=\frac{\text { number of scores obtained }}{\text { maximum number of scores }} \quad \text { x } 100 \%
$$

Criteria of validity value can be expressed by table 4

Table 4. Criteria for Validity Test

\begin{tabular}{|c|c|}
\multicolumn{2}{|c|}{ Table 4. Criteria for Validity Test } \\
\hline Level of Achievement & Category \\
\hline$<51$ & Poor \\
\hline $51-70$ & Weak \\
\hline $71-90$ & Good \\
\hline $91-100$ & Very Good \\
\hline
\end{tabular}

While for the analysis of practicality through questionnaire student response about multimedia learning is calculated by the formula with the following equation (2)

Practical Value $=\frac{\text { number of scores obtained }}{\text { maximum number of scores }} \times 100 \%$

By grouping the score according to that developed by Purwanto (2009) as table 5 .

Table 5. Criteria for practical test

\begin{tabular}{|c|c|c|}
\hline No & Level of Achievement & Category \\
\hline 1 & $90 \%-100 \%$ & Very Good \\
\hline 2 & $80 \%-89 \%$ & Good \\
\hline 3 & $65 \%-79 \%$ & Fair \\
\hline 4 & $55 \%-64 \%$ & Weak \\
\hline 5 & $0 \%-54 \%$ & Poor \\
\hline
\end{tabular}

While for the analysis of the effectiveness of multimedia learning, it is calculated based on the final test results of students with the formula:

$$
\text { Efectivity Value }=\frac{\text { Number of Students }}{\text { Number of Total students }} x 100 \%
$$

This criterion of multimedia effectiveness test scores refers to the opinion of Trianto (2010) as table 6.

Tabel 6. Criteria for effectiveness test

\begin{tabular}{|c|c|c|}
\hline No & Number of Percentages & Criteria \\
\hline 1 & $80 \%-100 \%$ & Good \\
\hline 2 & $51 \%-75 \%$ & Fair \\
\hline 3 & $26 \%-50 \%$ & Weak \\
\hline 4 & $0 \%-25 \%$ & Porr \\
\hline
\end{tabular}

\section{Results and Discussion}

The development of the module of PBL-oriented Statistics Education has passed the following stages:

\section{Analysis Stage}

At this stage through observation and interviews obtained information related to indicators Learning Outcome statistical learning, namely through this subject students are able to master the basic statistical concepts used in data processing research and using SPSS program as a tool in the practicum. From interviews with some students, students are characterized by students who tend to understand the courses if they use computer aids and work together in groups. The existing books and resources have not been shaped in a structured module that can make them learn independently. Based on the above, it is necessary to develop the module as a teaching material of the student oriented PBL.

\section{Design Stage}

Preliminary draft of the module by determining the number of learning activities to be made that corresponds to the $\mathrm{LO}$ and formulating the material items consisting of Chapters and Sub Chapters as well as the main parts of the Module (Development \& Vocational, 2008). Furthermore, writing the script module with the help of Microsoft Word 2010 applications and CorelDraw X4. The writing of the module is divided into 3 stages, namely: 1) Content writing module contents consisting of module titles, learning activities that contain material descriptions, summaries, and exercises, 2) Preliminary page writing containing cover, introduction, and table of contents, 3 ) Editing, after the draft module was written down then discussed with the research team members to get suggestions and inputs for improvement. Module cover design using Corel application as shown in Figure 2

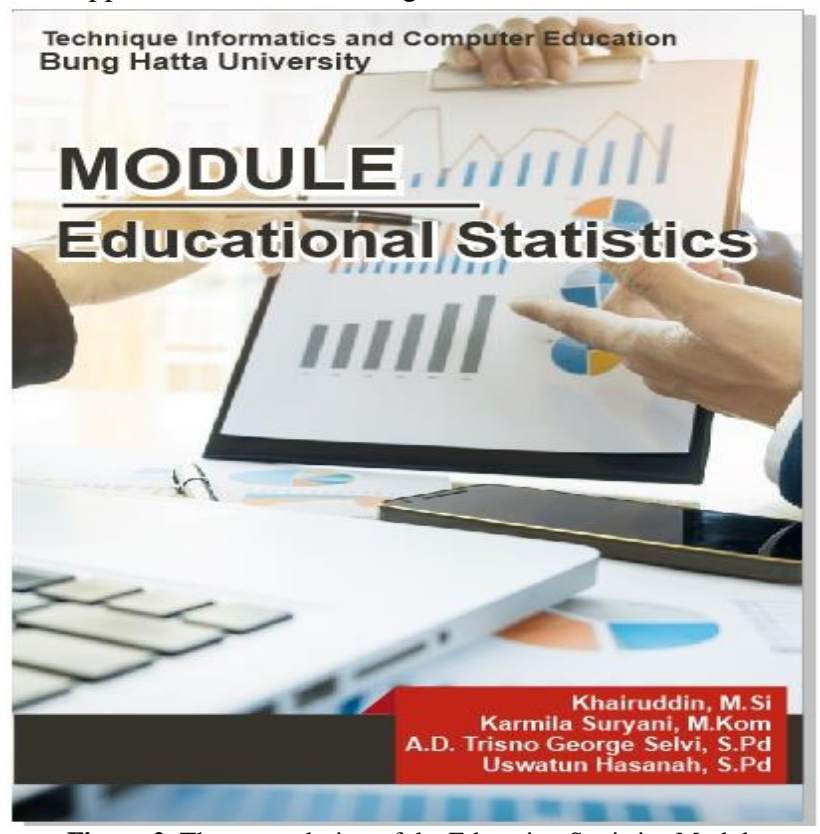

Figure 2. The cover design of the Education Statistics Module

The next to the module contents design, outlined above format; Title, Purpose, Theoretical Basis, Learning Activities, and Tasks. As shown in Figure 3.

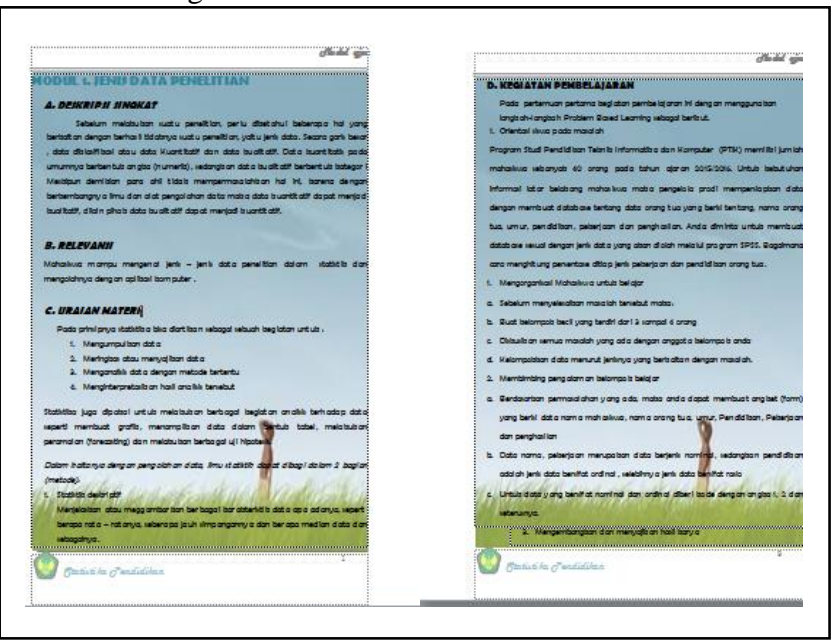

Figure 3. One of the Module Content for Early Learning Activities

\section{Development Stage}

At this stage the product is validated and revised based on an academic material expert (lecturer teaching statistics) and a media expert (graphicist). From questionnaires to three material experts obtained the results of recapitulation as table 7 . 
Table 7. Recapitulation of Validity Value of material experts

\begin{tabular}{|c|c|c|c|c|c|c|c|c|}
\hline \multirow[t]{2}{*}{ Aspect } & \multirow[t]{2}{*}{ Indicator } & \multicolumn{3}{|c|}{\begin{tabular}{|l|} 
Valida- \\
tor \\
\end{tabular}} & \multirow{2}{*}{$\begin{array}{l}\text { To- } \\
\text { tal }\end{array}$} & \multirow{2}{*}{$\begin{array}{l}\text { Maxscor } \\
\text { es }\end{array}$} & \multirow{2}{*}{$\begin{array}{c}\text { Valid- } \\
\text { ity } \\
(\%)\end{array}$} & \multirow[t]{2}{*}{ Criteria } \\
\hline & & 1 & 2 & 3 & & & & \\
\hline \multirow[t]{4}{*}{$\begin{array}{l}\text { Aspect of } \\
\text { Eligibil- } \\
\text { ity of } \\
\text { content }\end{array}$} & $\begin{array}{l}\text { B. Material } \\
\text { Compli- } \\
\text { ance with } \\
\text { LO }\end{array}$ & 9 & $\begin{array}{l}1 \\
1\end{array}$ & $\begin{array}{l}1 \\
0\end{array}$ & 30 & 36 & 83.3 & Good \\
\hline & $\begin{array}{ll}\text { E. } & \text { Material } \\
\text { Accuracy }\end{array}$ & $\begin{array}{l}2 \\
0 \\
\end{array}$ & $\begin{array}{l}1 \\
8 \\
\end{array}$ & $\begin{array}{l}1 \\
9 \\
\end{array}$ & 57 & 72 & 79.2 & Good \\
\hline & $\begin{array}{ll}\text { F. } & \text { Material } \\
& \text { Updates } \\
\end{array}$ & \begin{tabular}{l|}
1 \\
4 \\
\end{tabular} & \begin{tabular}{|l}
1 \\
3 \\
\end{tabular} & \begin{tabular}{l|}
1 \\
2 \\
\end{tabular} & 39 & 48 & 81.3 & Good \\
\hline & $\begin{array}{ll}\text { G. } & \text { Pushing } \\
& \text { Curiosity }\end{array}$ & 6 & 8 & 7 & 21 & 24 & 87.5 & Good \\
\hline \multirow[t]{4}{*}{$\begin{array}{l}\text { Aspect of } \\
\text { feasibility } \\
\text { of presen- } \\
\text { tation }\end{array}$} & $\begin{array}{l}\text { E. Presenta- } \\
\text { tion } \\
\text { Tech- } \\
\text { nique } \\
\end{array}$ & 7 & 6 & 8 & 21 & 24 & 87.5 & Good \\
\hline & $\begin{array}{ll}\text { F. } & \begin{array}{l}\text { Presenta- } \\
\text { tion Sup- } \\
\text { port }\end{array} \\
\end{array}$ & $\begin{array}{l}3 \\
1\end{array}$ & $\begin{array}{l}2 \\
4\end{array}$ & $\begin{array}{l}2 \\
6\end{array}$ & 81 & 96 & 84.4 & Good \\
\hline & $\begin{array}{l}\text { G. Presenta- } \\
\text { tion of } \\
\text { learning }\end{array}$ & 2 & 3 & 4 & 9 & 12 & 75.0 & Good \\
\hline & $\begin{array}{l}\text { H. Coher- } \\
\text { ence and } \\
\text { demands } \\
\text { of } \\
\text { thought } \\
\text { flow }\end{array}$ & 6 & 8 & 8 & 22 & 24 & 91.7 & $\begin{array}{l}\text { Very } \\
\text { Good }\end{array}$ \\
\hline $\begin{array}{l}\text { Aspects } \\
\text { of Prob- } \\
\text { lem Base } \\
\text { Learning } \\
\text { Orienta- } \\
\text { tion } \\
\text { (PBL) } \\
\end{array}$ & $\begin{array}{ll}\text { B. } & \text { PBL } \\
\text { compo- } \\
\text { nents }\end{array}$ & $\begin{array}{l}1 \\
2\end{array}$ & $\begin{array}{l}1 \\
4\end{array}$ & $\begin{array}{l}1 \\
8\end{array}$ & 44 & 60 & 73.3 & Good \\
\hline & & rag & & & & & 82.6 & Good \\
\hline
\end{tabular}

From table 7 it appears that all module components get good results. While the Recapitulation of Media experts such as table 8.

Table 8. Recapitulation of Values Validity of media experts

\begin{tabular}{|c|c|c|c|c|c|c|c|}
\hline \multirow[t]{2}{*}{ Aspect } & \multirow[t]{2}{*}{ Indicator } & \multicolumn{2}{|c|}{$\begin{array}{l}\text { Valida- } \\
\text { tor }\end{array}$} & \multirow{2}{*}{$\begin{array}{l}\text { To- } \\
\text { tal }\end{array}$} & \multirow{2}{*}{$\begin{array}{c}\text { Max } \\
\text { score } \\
\text { s }\end{array}$} & \multirow{2}{*}{$\begin{array}{l}\text { Validi- } \\
\text { ty }(\%)\end{array}$} & \multirow{2}{*}{$\begin{array}{c}\text { Crite- } \\
\text { ria }\end{array}$} \\
\hline & & 1 & 2 & & & & \\
\hline \multirow{3}{*}{$\begin{array}{l}\text { 1. Aspect } \\
\text { of feasi- } \\
\text { bility of } \\
\text { gradua- } \\
\text { tion } \\
\end{array}$} & Module size & 8 & 7 & 15 & 16 & 93.8 & $\begin{array}{l}\text { Very } \\
\text { Good }\end{array}$ \\
\hline & Cover design & 21 & 25 & 46 & 56 & 82.1 & Good \\
\hline & $\begin{array}{l}\text { Design Fill } \\
\text { module }\end{array}$ & 51 & 60 & 111 & 136 & 81.6 & Good \\
\hline \multirow{6}{*}{$\begin{array}{l}\text { 2. Lan- } \\
\text { guage } \\
\text { Feasibil- } \\
\text { ity As- } \\
\text { pect }\end{array}$} & $\begin{array}{l}\text { Straightfor- } \\
\text { ward }\end{array}$ & 9 & 11 & 20 & 24 & 83.3 & Good \\
\hline & $\begin{array}{l}\text { Communica- } \\
\text { tive }\end{array}$ & 3 & 4 & 7 & 8 & 87.5 & Good \\
\hline & $\begin{array}{l}\text { Dialogic Dan- } \\
\text { Interactive }\end{array}$ & 7 & 7 & 14 & 16 & 87.5 & Good \\
\hline & $\begin{array}{l}\text { Compliance } \\
\text { with the de- } \\
\text { velopment of } \\
\text { Learners }\end{array}$ & 8 & 7 & 15 & 16 & 93.8 & Good \\
\hline & $\begin{array}{l}\text { Compliance } \\
\text { with language } \\
\text { rules }\end{array}$ & 7 & 8 & 15 & 16 & 93.75 & $\begin{array}{l}\text { Very } \\
\text { Good }\end{array}$ \\
\hline & $\begin{array}{l}\text { Use of terms, } \\
\text { symbols or } \\
\text { icons }\end{array}$ & 7 & 7 & 14 & 16 & 87.5 & Good \\
\hline \multicolumn{6}{|c|}{ Average } & 87.9 & Good \\
\hline
\end{tabular}

From table 8 it can be seen that validation from 2 (two) media experts get the average of Good result. So it is feasible to be used for student implementation. Based on the results of questionnaires to students obtained results as shown by Figure 4

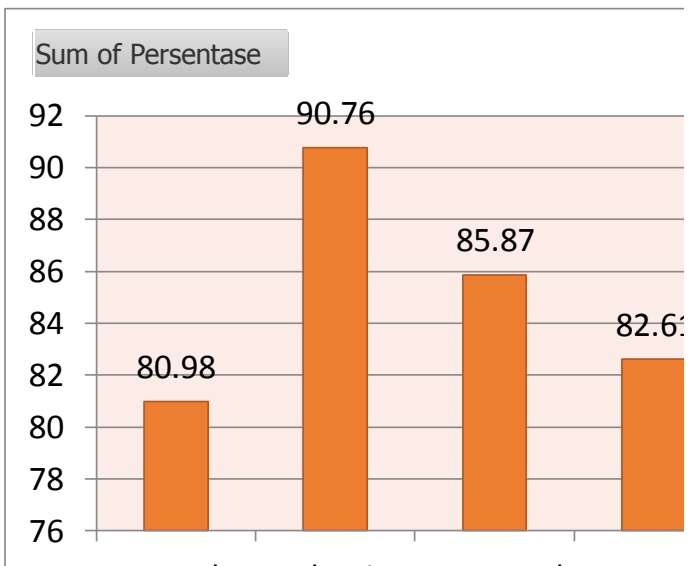

Figure 4. Re'capitulation of student practice' test

The result of figure 4 shows that the module designed is quite friendly and very good for student. As for the effectiveness test results obtained $65 \%$ of students passed in the test and can be stated that according to table 6 , the module developed quite effective.

\section{Conclusion and Recommendation}

Based on the results of the assessment of material and media experts it can be concluded that the Module is feasible to be used as teaching materials for the course of Education Statistics at the Faculty of Teacher Training and Education Bung Hatta University Padang. This module is only used for small-scale trials of informatics and computer science education students in the academic year 2017/2018. Further research will be tested on all bung hatta university studentsand tested by comparing between non-using modules. The anatomy of the module meets the standard format of the learning directorate general. this module also has no patent rights and will be registered soon.

It is even advisable to use it in other fields besides Teacher Training by developing for examples that intersect with areas of expertise. The next research will be developed e-learning module to better accommodate the development of IT today.

\section{Conflict of Interest}

The author declares no conflict of interest.

\section{Acknowledgments}

The authors acknowledge the support from Bung Hatta University, especially all of lecturers in the Faculty of Teacher Training and Education who have validated the module and the student of informatics and computer engineering education for the module use trials.

\section{References}

[1] Daryanto. Menyusun Modul Bahan Ajar Untuk Persiapan Guru dalam Mengajar. Yogyakarta: Gava Media; 2013.

[2] Wena M. Strategi Pembelajaran Inovatif Kontemporer (Suatu Tinjauan Konseptual Operasional). Jakarta: Bumi Aksara; 2010.

[3] Aisyah N, Purwoko. Peningkatan Hasil Belajar Mahasiswa menggunakan modul. J Ilmu Pendidik. 2011;17(5):393-400.

[4] Sengupta D, Huang Y, Davidson CI, Edgar TF, Eden M, ElHalwagi MM. Using Module-Based Learning Methods To Introduce Sustainable Manufacturing In Engineering Curriculum. 2017. 1-24 p.

[5] Wijana IM, Suardani AAP. Implementasi Uji Coba Modul-Modu Statistika Berbasis Spreadsheet Untuk Mahasiswa Trials Implementation of Spreadsheet Based Statistics Course Modules for Accounting Department of. J Pendidik Vokasi. 2016;6(3):272-80. 
[6] Surindra B. The Development of Economic Statistics II Module Based on Problem-Based Learning ( PBL ) in Nusantara PGRI University, Kediri. 2017;8(28):94-9.

[7] Tarmizi RA, Bayat S. Effects of problem-based learning approach in learning of statistics among university students. Procedia - Soc Behav Sci. 2010;8(5):384-92.

[8] Culatta Richard. The ADDIE Model. Instructional Design Expert.com. 2018. p. 1-2.

[9] Dikti DB. Panduan penyusunan perangkat pembelajaran \& bahan ajar 2017. 2017.

[10] Muljono P. Kegiatan Penilaian Buku Teks Pelajaran Pendidikan Dasar dan Menengah. Buletin BSNP. 2007;II(1):1-24.

[11] Purwanto. Prinsip-prinsip dan Teknik Evaluasi Pengajaran (principles and techniques of evaluation). Bandung: Remaja Rosdakarya 2009.

[12] Trianto. Model Pembelajaran Terpadu(Integrated learning model). Jakarta: Bumi Aksara; 2010. 